\title{
Fixed point theorems for Prešić almost contraction mappings in orbitally complete metric spaces endowed with directed graphs
}

\section{PORNPIMON BORIWAN ${ }^{1}$, NARIN PETROT ${ }^{1,2}$ and SUTHEP SUANTAI ${ }^{3}$}

\section{ABSTRACT.}

The main aim of this paper is to introduce a class of generalized contractions in product spaces in the sense of Prešić. Some examples and fixed point theorems for such introduced mappings in the setting of orbitally complete metric spaces are proved. The results presented here extend and include many existing several results in the literature.

Acknowledgements. This research has been funded by Naresuan University (R2559C234) and the Thailand Research Fund under the project RTA5780007.

\section{REFERENCES}

[1] Altun, I. and Acar, Ö., Multivalued almost contractions in metric space endowed with a graph, Creat. Math. Inform., 24 (2015), No. 1, 1-8

[2] Aydi, H., Hadj Amor, S. and Karapinar, E., Berinde-type generalized contractions on partial metric spaces, Abstract and Applied Analysis (2013) Article number 312479

[3] Aydi, H. Felhi, A. and Sahmim, S., Fixed points of multivalued nonself almost contractions in metric-like spaces, Math. Sci. (Springer), 9 (2015), No. 2, $103-108$

[4] Berinde, V., Approximation fixed points of weak contractions using the Picard iteration, Nonlinear Anal Forum, 9 (2004), 43-53

[5] Berinde, V., Some remarks on a fixed point theorem for Ćirić-type almost contractions, Carpath. J. Math., 25 (2009), 62-157

[6] Berinde, V. and Păcurar, M., An iterative method for approximating fixed points of Prešić nonexpansive mappings, Rev. Anal. Numér. Théor. Approx., 38 (2009), No. 2, 144-153

[7] Berinde, V. and Păcurar, M., Two elementary applications of some Prešić type fixed point theorems, Creat. Math. Inform., 20 (2011), No. 1, 32-42

[8] Chen, Y. Z., A Prešić type contractive condition and its applications, Nonlinear Anal., 71 (2009), 2012-2017

[9] Cho, S. -H., A fixed point theorem for a Ćirić-Berinde type mapping in orbitally complete metric spaces, Carpath. J. Math., 30 (2014), No. 1, 63-70

[10] Du, W. Karapinar, E. and Shahzad, N., The study of fixed point theory for various multivalued non-self-maps, Abstract and Applied Analysis, (2013) Article number 938724

[11] Dejan, I., Abbas, M. and Talat, N., Iterative approximation of fixed points of Prešić operators on partial metric spaces, Math. Nachr., 288 No. 14-15, (2015) 1634-1646, DOI:10.1002/mana.201400235

[12] Karapinar , E. and Sadarangani, K., Berinde mappings in ordered metric spaces, Revista de la Real Academia de Ciencias Exactas, Fisicas y Naturales - Serie A: Matematicas, 109 (2015), No. 2, 353-366

[13] Jachymski, J. and Jozwik, I., Nonlinear contractive conditions: comparison and related problems, Banach Cent. Publ., 77 (2007), 123-146

Received: 14.12.2015; In revised form: 14.05.2016; Accepted: 15.05.2016

2010 Mathematics Subject Classification. 47H10, 54H25.

Key words and phrases. Prešić operator, almost contraction mapping, orbitally complete metric space, directed graph, fixed point.

Corresponding author: N. Petrot; narinp@nu.ac.th 
[14] Khan, M. S., Berzig, M. and Samet, B., Some convergence results for iterative sequences of Prešić type and applications, Adv. Difference Equ., 2012 , 2012:38, 12 pp.

[15] Mustafa, Z., Karapinar, E. and Aydi, H., A discussion on generalized almost contractions via retional expressions in partially ordered metric spaces, J. Inequal. Appl., 2014, 2014:219, $12 \mathrm{pp}$.

[16] Păcurar, M., Approximating common fixed points of Prešić-Kannan type operators by a multi-step iterative method, An. Ştiinţ. Univ. “Ovidius"Constanţa Ser. Mat., 17 (2009), No. 1, 153-168

[17] Păcurar, M., Iterative methods for fixed point approximation, Editura Risoprint, Cluj-Napoca, 2009, 196 pp. ISBN:978-973-53-0068-5

[18] Păcurar, M., A multi-step iterative method for approximating fixed points of Prešić-Kannan operators, Acta Math. Univ. Comenian. (N.S.), 79 (2010), No. 1, 77-88

[19] Păcurar, M., A multi-step iterative method for approximating common fixed points of Prešić-Rus type operators on metric spaces, Stud. Univ. Babeş-Bolyai Math., 55 (2010), No. 1, 149-162

[20] Păcurar, M., Fixed points of almost Prešićć operators by a k-step iterative method, An. Ştiinţ. Univ. Al. l. Cuza laşi Mat. (N.S.), 57 (2011), suppl. 1, 199-210

[21] Păcurar, M., Common fixed points for almost Prešić typ operators, Carpathian J. Math., 28 (2012), No. 1, 117-126

[22] Prešić, S. B., Sur la convergence des suites, C. R. Acad. Sci. Paris, 260 (1965), 3828-3830

[23] Prešić, S. B., Sur une classe d'inquations aux différences finite et sur la convergence de certaines suites, Publ. Inst. Math., (Belgr.) 5 (1965), 75-78

[24] Shaddad, F., Noorani, M. S. M. and Alsulami, S. M., Common fixed-point results for generalized Berinde-type contractions which involve altering distance functions, Fixed Point Theory and Appl., 2014, 2014:24

[25] Shukla, S. and Shahzad, N., G-Prešić operators on metric spaces endowed with a graph and fixed point theorems, Fixed Point Theory and Appl., 2014, 2014:127, 10 pp.

[26] Türkoğlu, D., Özer, O. and Fisher, B., Fixed point theorems for T-orbitally complete spaces, Mathematica, 9 (1999), 211-218

\author{
${ }^{1}$ Department of Mathematics \\ FACULTY OF SCIENCE \\ NARESUAN UNIVERSITY \\ PHITSANULOK, 65000, THAILAND \\ E-mail address: boriwap_1990@hotmail.co.th \\ ${ }^{2}$ NARESUAN UNIVERSITY \\ RESEARCH CENTER FOR ACADEMiC EXCELlENCE IN MATHEMATICS, \\ FACULTY OF SCIENCE \\ PHITSANULOK, 65000, THAILAND \\ E-mail address: narinp@nu.ac.th \\ ${ }^{3}$ Department OF MATHEMATiCs \\ FACULTY OF SCIENCE \\ CHIANG MAI UNIVERSITY \\ CHIANG MAI, 50200, THAILAND \\ E-mail address: suthep.s@ cmu. ac.th
}

